\title{
Kommentti: Mitä lukion äidinkielen ylioppilaskokeessa pitäisi arvioida?
}

Teknisen uudistuksen lisäksi äidinkielen ylioppilaskokeen digitalisoituminen merkitsee rakenteellisesti uudentyyppistä koetta: tekstitaidon ja esseekokeen korvaavat syksystä 2018 alkaen lukutaidon ja kirjoitustaidon kokeet. Kuten Outi Ojan ja Satu Kiiskisen esityksistä käy ilmi, tämä tarkoittaa tehtävätyyppien ja kohteena olevien sisältöjen monipuolistumista. Tulevat muutokset herättävät monia kysymyksiä, joista vähäisin ei ole se, millä eväin opettajat ja oppilaat voivat jatkossa ylioppilaskokeeseen valmistautua, kun analyysin kohteeksi voi tulla esimerkiksi katkelma taltioitua teatteriesitystä, tv-ohjelmaa, elokuvaa, musiikkivideota, radiohaastattelua tai kuunnelmaa. Lisäksi edellytetään erilaisten fiktiivisten ja asiatekstien analyysin hallitsemista, kuten aiemmassakin koemuodossa.

Lukion opetussuunnitelmat ovat Suomessa suhteellisen väljiä, mikä haastaa paikallisten opetussuunnitelmien laatijat, oppikirjojen tekijät ja viime kädessä opettajat pohtimaan olennaisia käsitteitä, tietoja ja taitoja, joiden varassa oppilaat voi päättökokeen ääreen tuoda. Ei ole yllättävää, jos tulevina vuosina keskustelu äidinkielen ja kirjallisuuden oppiaineen sisällöistä ja päättökokeessa vaadittavista taidoista jatkuu vilkkaana. Opetuskenttä jakautuu ja pahimmassa tapauksessa epätasa-arvoistuu. Mitä enemmän opetussuunnitelmissa ja päättökokeissa on epävarmuustekijöitä, sitä enemmän opettajat ovat oman harkintakykynsä varassa.

Kirjallisuudentutkijoita kiinnostanee kysymys, miten kaunokirjallisuuden käy uudistusten pyörteissä. Periaatteessa tuleva päättökoe edellyttää kaikilta oppilailta kaunokirjallisuuden analyysitaitoja, mutta huolta herättää se, missä määrin kouluissa ehditään käsitellä ja lukea kaunokirjallisuutta, kun selvästi aiempaa enemmän pitäisi keskittyä audiovisuaalisten tekstien analysointiin.

YTL:n tiedotteen mukaan "lukutaidon kokeessa arvioidaan kokelaan kriittistä ja kulttuurista lukutaitoa eli taitoa eritellä, tulkita, arvioida ja hyödyntää monimuotoisia tekstejä tietoisena niiden tavoitteista, ilmaisukeinoista ja konteksteista" (YTL 2017, 3). Oppilaiden tulee siis harjoitella paitsi eri tekstimuotojen analyysia myös näiden monimuotoisten tekstien tavoitteita ja konteksteja, jotka tekstirepertuaarin huomioon ottaen laajenevat moniaalle. Tämänkaltaiseen eri genret ylittävään analyysiin Outi Ojan kehittelemä lukumalli kirjassaan Kohti kokonaisvaltaista tulkintaa. Työkaluja äidinkielen ja kirjallisuuden sähköiseen ylioppilaskokeeseen (2017) vaikuttaa toimivalta. 
Olen toisaalla (HS 9.12.2017) esittänyt, että tulevaisuuden äidinkielen ja kirjallisuuden opetuksen keskiössä tulisi jatkossakin olla lukemisen, kirjoittamisen, puhumisen ja ajattelun perusteet eli kieli ja siihen läheisesti liittyvä kirjallisuus, jonka merkitys kirjoitus- ja lukutaidon ja erityisesti ajattelun kehittämisessä on olennaista. Kielen monimuotoisuuteen ja eri ilmaisutapoihin pääsee oppitunneilla käsiksi painettujen tekstien ohella myös audiovisuaalisten tekstien tai vaikkapa laulujen sanoitusten kautta, mutta ovatko nämä välttämättömiä aineistoja päättökokeessa? Vai onko ajateltava, että yhteiskuntamme on jo siinä määrin audiovisualisoitunut, että perinteinen tekstuaalinen kulttuuri (kirjoitettujen tekstien lukeminen ja tuottaminen) ja puhuminen on vanhanaikaista ja sellaisia taitoja, jotka jäävät vähemmälle työelämässä?

Huomio kiinnittyy lisäksi siihen, mitä oppilailta vaaditaan tekstien tuottajina. Uudessa kirjoitustaidon kokeessa oppilas kirjoittaa laajahkon yhtenäisen tekstin, mutta lukutaidon kokeeseen voi tulla tehtäviä, joissa vastaamiseen riittää luettelon laatiminen (YTL 2017, 6-7). Oppilaan vastaus voi tosiaan olla niin kutsutuin ranskalaisin viivoin tehty luetelma. Lukutaidon kokeen vastauksia arvioidessaan opettaja ei merkitse kieliasuun liittyviä virheitä. Ehkä tulevaisuudessa päädytään jopa monivalintakysymyksiin.

Nykyinen lukion äidinkielen ja kirjallisuuden opetussuunnitelma on aiempaa enemmän suuntautunut nykyajan ilmiöihin. Siinä esimerkiksi kirjallisuushistorian opiskelu on lähes puolitettu aiemmasta opetussuunnitelmasta, ja yksi kurssi on kokonaan omistettu nykykulttuurille. Kun nykylukion läpikäyneet oppilaat tulevat yliopistoon, tuntuu aiempaa tärkeämmältä nostaa esille historiaperspektiivin merkitys erilaisten ilmiöiden, kuten kirjallisuuden, käsittelyssä. Niin ikään voidaan odottaa, että opiskelijat kokevat vaikkapa laajojen esseiden kirjoittamisen entistä vaikeampana aiempaa heikomman kontekstitietoisuuden takia.

\section{Lähteet:}

Mäkikalli, Aino ja Päivi Laine 2017. Onko äidinkielen ja kirjallisuuden oppiaineen sisältöä paisutettu jo liikaa? Helsingin Sanomat 9.12.2017.

YTL 2017. Tiedote äidinkielen opettajille ja opiskelijoille. Äidinkielen digitaalinen ylioppilaskoe. Ylioppilastutkintolautakunta. Julkaistu 15.12.2017. https://www.ylioppilastutkinto.fi/images/ sivuston_tiedostot/Sahkoinen_tutkinto/aidinkieli_tiedote_15.12.2017_fi.pdf (tieto haettu 19.12.2017).

\section{Aino Mäkikalli}

